\title{
Costs of living in metal polluted areas: respiration rate of the ground beetle Pterostichus oblongopunctatus from two gradients of metal pollution
}

\author{
Agnieszka J. Bednarska • Izabela Stachowicz
}

Accepted: 9 October 2012/Published online: 23 October 2012

(C) The Author(s) 2012. This article is published with open access at Springerlink.com

\begin{abstract}
To address the question about costs of living in polluted areas, biomarkers linked to metabolism were measured in Pterostichus oblongopunctatus (Coleoptera: Carabidae) collected along two metal-pollution gradients in the vicinity of the two largest Polish zinc smelters: 'Bolesław' and 'Miasteczko Śląskie' in southern Poland. Both gradients covered a broad range of $\mathrm{Zn}$ and $\mathrm{Cd}$ concentrations in the humus layer (109-6151 and $1.48-71.4 \mathrm{mg} \mathrm{kg}^{-1}$, respectively) and body metal concentrations increased with increasing soil metal concentrations. The whole-organism respiration rate was measured as oxygen consumption with Micro-Oxymax respirometer, and cellular energy consumption-as the activity of electron transport system, which is linked to cellular respiration rate. The significant increase in the whole-organism respiration rate with the body metal concentration was found when taking into account other factors such as body mass, gradient (or year of sampling as the beetles were collected on the gradients in different years) and the interactions: body metal concentrations $\times$ collection date, body metal concentrations $x$ body mass, and body mass $\times$ gradient/sampling year. However, no relationships between metal concentrations in soil or body metal concentrations and the whole-organism or cellular respiration rate could be detected when using mean values per site, underlining the crucial importance of incorporating individual variability in such analyses. The observed increase of the whole-organism respiration rate with increasing body contamination with metals suggests that $P$. oblongopunctatus incurs energetic expenditures resulting from the necessity to
\end{abstract}

\footnotetext{
A. J. Bednarska $(\bowtie) \cdot$ I. Stachowicz

Institute of Environmental Sciences, Jagiellonian University,

Gronostajowa 7, 30-387 Kraków, Poland

e-mail: a.bednarska@uj.edu.pl
}

facilitate metal elimination or repair of toxicant-induced damage.

Keywords Zinc $\cdot$ Cadmium $\cdot$ Carabids $\cdot$ Energetic costs

\section{Introduction}

Metals are persistent pollutants, with strong direct and indirect impacts on invertebrates (Posthuma and van Straalen 1993). Direct physiological effects may occur by alteration or inhibition of various enzymatic pathways, while indirect effects can be not only physiological (e.g. lipid peroxidation caused by produced reactive oxygen species (Wilczek et al. 2004)) but may be also observed as pollution-driven changes in reproduction or survival due to diminished energy budget (Posthuma and Van Straalen 1993). Some indirect evidence of increased detoxification costs are available for invertebrates exposed to elevated metal concentrations, for example smaller body size of woodlice Porcellio scaber (Jones and Hopkin 1998) and lower reproduction of the ground beetle Pterostichus oblongopunctatus (Łagisz et al. 2002) or their decreased tolerance to other stressors (Stone et al. 2001).

Oxygen consumption is a direct measure of respiratory metabolism and allows, thus, for drawing conclusions about an organism's maintenance costs (Calow 1991). Because the respiration rate is relatively easy to measure, it is often used as the equivalent for a metabolic rate (Migula 1989; Handy and Depledge 1999). It can serve as a convenient end-point in studies in which effect of toxicants (as well as other factors) on metabolic rate may be expected. A general prediction that results from models involving metabolically costly physiological responses is that metabolic rate should increase with increasing intoxication 
(exposure time and/or concentration) until irreversible pathological effects impair metabolism itself (Calow 1989). Indeed, laboratory studies on animals treated for several generations with cadmium (beet armyworm, Spodoptera exigua; Kramarz and Kafel 2003) or copper (confused flour beetle, Tribolium confusum; Lukasik and Laskowski 2007) revealed elevated whole-body respiration rates in the exposed individuals. Laskowski et al. (1996) showed that the respiration rate of centipedes treated with copper increased for only a short period and returned later to the same level as in control animals. In turn, Migula (1989) noticed a decrease in the respiratory metabolism in house crickets (Acheta domesticus) intoxicated with cadmium, while zinc and lead did not cause any effect.

Data on whole-body respiration rates of terrestrial invertebrates inhabiting metal polluted sites are scarce (Lagisz et al. 2005). Even less data are available for respiratory metabolism of terrestrial invertebrates measured at the cellular level. This can be done by measuring the activity of the electron transport system (ETS) in mitochondria. Although this technique was initially developed to estimate respiration of phytoplankton and zooplankton species (Kenner and Ahmed 1975) and then validated for Daphnia magna (De Coen and Janssen 1997), it can also be used for other invertebrates (Moolman et al. 2007; Olsen et al. 2007).

The aim of this study was to relate respiration rates measured at organismal and cellular levels in field-collected animals to metal pollution. The respiration rates were measured in the ground beetle $P$. oblongopunctatus (Coleoptera: Carabidae) collected from sites differently contaminated with metals. We hypothesized an increase in metabolic rates with increasing body metal contamination as a result of energetically costly processes of metal detoxification (Sibly and Calow 1989), such as, e.g., production of metallothioneins and metal-containing granules (Hopkin 1989; Walker et al. 2006). The respiration rates were measured at two different levels because they may indicate different effects. The effect on the whole-organism respiration rate $(\mathrm{R})$ would represent the long-term effect of chronic exposure to the metals, while ETS - the instantaneous maximum respiration rate at the sampling time; we expected the ETS to be prone to rapid temporal changes in conditions - as is the case for most biochemical biomarkers.

\section{Materials and methods}

\section{Sampling sites}

To control, as far as possible, for stress factors other than metals, the study was performed on animals collected along two distinct transects traced from two metal smelters. The clear metal pollution gradient was found for both transects.
Adult beetles were collected from six sites along a metal-pollution gradient in the vicinity of the 'Bolesław' zinc smelter in Olkusz (OLK) area and from six sites around Miasteczko Śląskie (MSL) zinc smelter. The sampling sites were chosen based on $\mathrm{Zn}$ and $\mathrm{Cd}$ concentrations in the humus layer to provide a wide range of pollution levels (Stefanowicz et al. 2008; Tarasek 2011). The concentrations were ( $\mathrm{mg} \mathrm{kg}^{-1}$ dry weight): $\mathrm{Zn}, 109-6151$ and $\mathrm{Cd}, 1.5-71.4$ at OLK gradient and Zn, 155-2906 and Cd, 2.2-55 at MSL gradient (Table 1). Although the same unpolluted site was used in both gradients, it was labeled by different metal concentrations in the soil: metal concentrations measured by Stefanowicz et al. (2008) were used for the OLK unpolluted site, and metal concentrations measured by Tarasek (2011) were used for the MSL unpolluted site. All sites at both pollution gradients were located in Scots pine forests on sandy podsolized soils.

The beetles were sampled with pitfall traps. Ninety traps were distributed per site and emptied every second or third day between April 24 and May 15, 2008 at the OLK transect, and in the same period in 2010 at the MSL transect. After transporting to the laboratory, the beetles were separated by sex, placed individually in 30-ml plastic vials and kept in a controlled temperature chamber $\left(20{ }^{\circ} \mathrm{C}, 60 \%\right.$ relative humidity, 16:8 light:dark photoperiod) for $24 \mathrm{~h}$ to void gut contents. The beetles were then weighed to the nearest $0.0001 \mathrm{~g}$ on an electronic balance (AS 160/C/2 Radwag, Poland). Because of the limited number of chambers in the respirometer (30), $\mathrm{R}$ was measured in a maximum of five males from each site and sampling date. After measurements, the beetles were weighed and frozen at $-20{ }^{\circ} \mathrm{C}$ for metal analysis. The body concentrations of $\mathrm{Zn}$ and $\mathrm{Cd}$ were analyzed by flame $(\mathrm{Zn})$ or by graphite furnace (Cd) atomic absorption spectrometry (PerkinElmer AAnalyst 800) after wet digestion in boiling $\mathrm{HNO}_{3}$, as described by Bednarska et al. (2012). The beetles used for ETS analysis (ten males per site) were frozen in liquid nitrogen after $24-\mathrm{h}$ starvation and stored at $-80{ }^{\circ} \mathrm{C}$.

\section{Respiration rate measurements}

The beetles were placed individually into $50 \mathrm{ml}$ flasks connected to a 30-channel computer-controlled, closedcircuit Micro-Oxymax respirometer (Columbus Instruments, USA). The animals from different sites were assigned to the flasks at random. Along with the beetles, a punctured Eppendorf tube filled with distilled water and a hole in the lid was placed in each bottle to prevent desiccation. The respiration rate was measured over $28 \mathrm{~h}$ at $4-\mathrm{h}$ intervals at 16:8 L:D and $20^{\circ} \mathrm{C}$. Respiration rate was measured as oxygen consumption per hour per beetle and then recalculated per gram body mass for data analysis $\left(\mu l \mathrm{O}_{2} \mathrm{~g}^{-1} \mathrm{~h}^{-1}\right)$. The data were not corrected for oxygen 
Table 1 Metal concentrations in the humus layer and in the ground beetles $P$. oblongopuncatus (mean \pm SD) and calculated pollution indices $(\mathrm{PI})^{\mathrm{a}}$ along two metal pollution gradients

\begin{tabular}{|c|c|c|c|c|c|c|c|c|c|c|}
\hline \multirow[t]{2}{*}{ Gradient } & \multirow[t]{2}{*}{ Location } & \multirow{2}{*}{$\begin{array}{l}\text { Distance } \\
\text { from } \\
\text { nearest } \\
\text { smelter } \\
(\mathrm{km})\end{array}$} & \multicolumn{3}{|c|}{ Metals in soil ${ }^{\mathrm{b}}$} & \multicolumn{3}{|c|}{ Metals in beetles } & \multirow{2}{*}{$\begin{array}{l}\text { Whole-body } \\
\text { respiration } \\
\text { rate } \\
\qquad\left(\mu 1 \mathrm{O}_{2} \mathrm{~h}^{-1}\right.\end{array}$} & \multirow{2}{*}{$\begin{array}{l}\text { Cellular } \\
\text { respiration } \\
\text { rate } \\
\mathrm{g}^{-1} \text { bw) }\end{array}$} \\
\hline & & & \multicolumn{2}{|c|}{$\left(\mathrm{mg} \mathrm{kg}^{-1} \mathrm{dw}\right)$} & \multirow{2}{*}{$\begin{array}{l}\text { PI } \\
52.3\end{array}$} & \multicolumn{2}{|c|}{$\mathrm{Cd}_{\left(\mathrm{mg} \mathrm{kg}^{-1} \mathrm{dw}\right)}^{\mathrm{Zn}}$} & \multirow{2}{*}{$\begin{array}{l}\text { BCI } \\
2.25\end{array}$} & & \\
\hline & $\begin{array}{l}50^{\circ} 17^{\prime} \mathrm{N} \\
19^{\circ} 29^{\prime} \mathrm{E}\end{array}$ & 1.9 & 71.4 & 6,151 & & $2.5 \pm 2.21(23)^{\mathrm{c}}$ & $115 \pm 15$ & & $449 \pm 74$ & $4,771 \pm 2,121$ \\
\hline & $\begin{array}{l}50^{\circ} 18^{\prime} \mathrm{N} \\
19^{\circ} 29^{\prime} \mathrm{E}\end{array}$ & 3.9 & 39.1 & 1,763 & 21.3 & $1.6 \pm 1.11$ & $107 \pm 15$ & 1.61 & $447 \pm 55$ & $5,282 \pm 1,929$ \\
\hline \multirow[t]{3}{*}{ OLK } & $\begin{array}{l}50^{\circ} 19^{\prime} \mathrm{N} \\
19^{\circ} 30^{\prime} \mathrm{E}\end{array}$ & 5.3 & 14.7 & 1,253 & 10.7 & $1.6 \pm 0.97$ & $103 \pm 10(23)$ & 1.62 & $442 \pm 54(23)$ & $4,106 \pm 2,262$ \\
\hline & $\begin{array}{l}50^{\circ} 19^{\prime} \mathrm{N} \\
19^{\circ} 32^{\prime} \mathrm{E}\end{array}$ & 7.9 & 12.2 & 755 & 7.6 & $1.8 \pm 1.10$ & $104 \pm 15$ & 1.73 & $423 \pm 54$ & $6,019 \pm 2,792$ \\
\hline & $\begin{array}{l}50^{\circ} 25^{\prime} \mathrm{N} \\
19^{\circ} 38^{\prime} \mathrm{E}\end{array}$ & 19.6 & 4.03 & 224 & 2.4 & $0.6 \pm 0.48$ & $99 \pm 90(24)$ & 0.94 & $452 \pm 59$ & $5,026 \pm 2,112$ \\
\hline \multirow[t]{3}{*}{$\begin{array}{r}\text { Unpolluted } \\
\text { site } 2008\end{array}$} & $\begin{array}{l}50^{\circ} 32^{\prime} \mathrm{N} \\
19^{\circ} 39^{\prime} \mathrm{E}\end{array}$ & 31.8 & 1.48 & 109 & 1.0 & $0.7 \pm 0.65$ & $100 \pm 11$ & 1.00 & $432 \pm 59$ & $4,995 \pm 2,046$ \\
\hline & $\begin{array}{l}50^{\circ} 29^{\prime} \mathrm{N} \\
18^{\circ} 57^{\prime} \mathrm{E}\end{array}$ & 2.1 & $52 \pm 10.6$ & $2,684 \pm 689$ & 20.5 & $3.7 \pm 1.89$ & $104 \pm 16(32)$ & 4.76 & $535 \pm 97(30)$ & $4,453 \pm 2,855$ \\
\hline & $\begin{array}{l}50^{\circ} 31^{\prime} \mathrm{N} \\
18^{\circ} 56^{\prime} \mathrm{E}\end{array}$ & 2.6 & $55 \pm 12.1$ & $2,906 \pm 726$ & 21.9 & $3.4 \pm 1.41$ & $106 \pm 17$ & 4.39 & $562 \pm 127(40)$ & $6,092 \pm 3,164$ \\
\hline \multirow[t]{3}{*}{ MSL } & $\begin{array}{l}50^{\circ} 31^{\prime} \mathrm{N} \\
18^{\circ} 57^{\prime} \mathrm{E}\end{array}$ & 3.3 & $36 \pm 10.1$ & $1,886 \pm 520$ & 14.3 & $2.3 \pm 1.19(51)$ & $101 \pm 15$ & 3.12 & $506 \pm 89$ & $3,566 \pm 1,829$ \\
\hline & $\begin{array}{l}50^{\circ} 32^{\prime} \mathrm{N} \\
18^{\circ} 57^{\prime} \mathrm{E}\end{array}$ & 5.1 & $5,9 \pm 1.5$ & $292 \pm 68$ & 2.3 & $1.4 \pm 0.51$ & $105 \pm 16$ & 2.12 & $511 \pm 78$ & $3,880 \pm 2,059$ \\
\hline & $\begin{array}{l}50^{\circ} 34^{\prime} \mathrm{N} \\
19^{\circ} 58^{\prime} \mathrm{E}\end{array}$ & 8.7 & $4.8 \pm 2.3$ & $319 \pm 80$ & 2.1 & $0.9 \pm 0.44(35)$ & $100 \pm 15(36)$ & 1.53 & $525 \pm 118$ & $3,165 \pm 1,776$ \\
\hline $\begin{array}{r}\text { Unpolluted } \\
\text { site } 2010\end{array}$ & $\begin{array}{l}50^{\circ} 32^{\prime} \mathrm{N} \\
19^{\circ} 39^{\prime} \mathrm{E}\end{array}$ & 31.8 & $2.2 \pm 1.8$ & $155 \pm 28$ & 1.0 & $0.4 \pm 0.37(41)$ & $95 \pm 14$ & 1.00 & $512 \pm 110(40)$ & $4,536 \pm 1,626$ \\
\hline
\end{tabular}

OLK Olkusz, MSL Miasteczko Slaskie

a Pollution and Body Concentration indices were calculated according to the equation $\mathrm{PI}=\frac{\mathrm{Zn}_{i} / \mathrm{Zn}_{U}+\mathrm{Cd}_{i} / \mathrm{Cd}_{U}}{2}$, where index $i$ denotes site number, index $U$

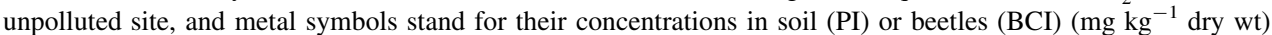

b Data for soil concentration for OLK gradient from Stefanowicz et al. (2008) and for MSL gradient from Tarasek (2011), no SD indicated for OLK gradient as chemical analysis were performed on mixed samples

c Number of beetles analyzed after outlier elimination

consumption by microbial growth in the flasks; our previous study indicated that the oxygen consumption in a control flask (without beetles but with Eppendorf-type tube with distilled water) was below $10 \%$ of the flask with the beetle. Prior to data analysis, the first measurement point (the first 4-h interval) for each individual was discarded, since we suspected that the change of the environment and handling stress might temporarily cause abnormal activity and respiration rates. Animals that died in the course of the measurements were excluded from the study.

\section{Cellular respiration rate measurements}

The energy consumption or cellular respiration rate was determined by measuring the activity of ETS. The ETS consists of a complex chain of macroenzymes (cytochromes, flavoproteins) in cell mitochondria that transport electrons for energy production. Since the synthesis and degradation of these macroenzymes is a function of the respiratory requirements of the organism, measuring ETS activity (also known as dehydrogenase activity) provides a time-averaged value of the maximum oxygen uptake rate (De Coen and Janssen 2003). The ETS was measured according to the method developed by De Coen and Janssen (1997) with minor modifications as described below.

Legs, elytra, and wings were carefully removed from each beetle using forceps and a scalpel and the remaining body parts of each individual were homogenized on ice using a PRO 200 mechanical homogenizer (Bioeko, Poland). The samples were homogenized on ice in $600 \mu \mathrm{l}$ of ice-cold homogenizing buffer [0.08 M Tris-HCL pH 8.5, $15 \%$ (w/v) Poly Vinyl Pyrrolidone, $153 \mu \mathrm{M} \mathrm{MgSO}$, and $0.2 \%(\mathrm{w} / \mathrm{v})$ Triton X-100]. After centrifugation $\left(1,000 \times g\right.$., $\left.10 \mathrm{~min}, 4{ }^{\circ} \mathrm{C}\right), 50 \mu \mathrm{l}$ of diluted supernatant was 
added to $150 \mu \mathrm{l}$ buffered substrate solution [0.13 mM Tris$\mathrm{HCl}, 0.3 \%$ (w/v) Triton X-100, pH 8.5, 1.7 mM NADH and $250 \mu \mathrm{M}$ NADPH]. The colorimetric reaction was started by adding $100 \mu \mathrm{l}$ of reagent solution [8 mM 2-piodo-phenyl-3-p-nitrophenyl 5-phenyl tetrazolium chloride, INT] and the absorbance was measured kinetically at $490 \mathrm{~nm}$ every $36 \mathrm{~s}$ for $3 \mathrm{~min}$ at $20^{\circ} \mathrm{C}$. The formazan production was determined from absorbance of the sample against the blank by using $\varepsilon=15,900 \mathrm{M}^{-1} \mathrm{~cm}^{-1}$.

The cellular respiration rate was determined from ETS data, based on the theoretical stoichiometric relationship that for each $2 \mu \mathrm{M}$ of formazan formed, $1 \mu \mathrm{M}$ of oxygen is consumed by the electron transport system. The quantity of oxygen consumed was expressed per $g$ body mass $\left(\mu \mathrm{l} \mathrm{O} \mathrm{g}^{-1} \mathrm{~h}^{-1}\right)$.

\section{Statistical analysis}

Prior to statistical analysis, outliers with the absolute values of modified MAD z-score greater than 3.5 were excluded and the distributions of the remaining data were checked for normality with Shapiro-Wilk's $W$ test. When this condition was not met, statistical analyses were performed on log-transformed data.

Correlations between $\mathrm{Zn}$ and $\mathrm{Cd}$ concentrations in soil and in the beetles were checked using Pearson correlation analysis. Because the metals in the soil were highly correlated with each other $(r=0.99, p<0.0001)$ and with body concentrations ( $r$ in the range $0.76-0.91, p \leq 0.003$ ), the study sites were described with a single measure of pollution by defining a Pollution Index (PI):

$\mathrm{PI}=\frac{\mathrm{Zn}_{i} / \mathrm{Zn}_{U}+\mathrm{Cd}_{i} / \mathrm{Cd}_{U}}{2}$

where index $i$ denotes site number at the particular transect, index $U$ site with the lowest metal concentration at this transect (unpolluted site), and metal symbols stand for their concentrations in soil. Different metal concentrations for the same unpolluted site in 2008 and 2010 were used to take into account possible temporal effects and differences in soil sampling and metal analysis procedures done by different people.

Similarly, a high correlation between $\mathrm{Zn}$ and $\mathrm{Cd}$ body concentrations ( $r=0.8, p=0.004$ ) was found and a body contamination index (BCI) was calculated to summarize internal concentrations of metals in the beetles originating from each study site:

$\mathrm{BCI}=\frac{\mathrm{Zn}_{i} / \mathrm{Zn}_{U}+\mathrm{Cd}_{i} / \mathrm{Cd}_{U}}{2}$

where metal symbols stand for their concentrations in beetles. In addition, $\mathrm{BCI}_{i}$ was calculated for each individual separately in a similar way, but $\mathrm{Zn}_{i}$ and $\mathrm{Cd}_{i}$ denoted internal concentrations of metals in individual $i$, and instead of site with the lowest metal concentration at the gradient (unpolluted site) - the beetle with the lowest concentration at the transect was used $\left(\mathrm{Zn}_{\min }\right.$ and $\left.\mathrm{Cd}_{\min }\right)$.

The simple regression analysis was performed to verify the effect of pollution (expressed as PI) on body metal concentrations (expressed as BCI) across all studied sites. The comparison of the regression lines was performed to check for possible effect of the sampling at two different gradients/years on the impact of metal pollution on metal accumulation.

Because the beetles were collected from the same unpolluted site in 2008 and 2010, possible differences in respiration rates between the years which might result from factors other than metal pollution, were tested for this site using a $t$ test.

Multiple-regression was used to find out which variables and their interactions affected the endpoints measured. The independent variables in the model for $\mathrm{R}$ were: $\mathrm{BCI}_{i}$, body mass, collection day and gradient (or sampling year, as it was not possible to separate the effect of different years of sampling from the gradient as such, due to the beetle sampling schedule: the beetles were collected on each gradient in different years). The interactions and variables with the highest $\mathrm{p}$ value were removed consecutively from the model (backward stepwise procedure with cut-off value $F=4.0$ ) as long there were any interactions/variables with $p>0.05$.

Due to technical reasons the concentrations of $\mathrm{Cd}$ and $\mathrm{Zn}$ could not be measured in the same animals in which ETS values were assessed. Therefore, the multiple regression analysis for ETS was done on mean values with PI and gradient as independent variables. Because of this limitation, neither body mass nor collection day could be included in the analysis. For comparison, also $\mathrm{R}$ was reanalyzed in that way.

The relationship between mean $\mathrm{R}$ and mean ETS was checked using reduced major axis regression (RMA).

All statistical analyses except RMA were performed with Statgraphics Centurion XVI (StatPoint Technologies, Inc., USA), and PAST (http://folk.uio.no/ohammer/past) was used for RMA.

\section{Results}

Among 144 values of body $\mathrm{Zn}$ or Cd concentrations at the OLK gradient, three values for $\mathrm{Cd}$ and two for $\mathrm{Zn}$ were excluded from statistical analysis as outliers. For MSL ( $n=231)$, eleven outliers for body Cd concentration were excluded. In respiration rate measurements seven beetles (one from OLK and six from MSL) which died and ten outliers (one from OLK and nine from MSL) were excluded from statistical analysis. 
The highest concentrations of $\mathrm{Zn}$ and $\mathrm{Cd}$ in soil were found at OLK gradient at the site nearest to the smelter $\left(6,151\right.$ and $71.4 \mathrm{mg} \mathrm{kg}^{-1}$, respectively). The highest body concentrations of $\mathrm{Zn}$ were found in beetles collected from the Olkusz gradient (mean $115 \mathrm{mg} \mathrm{kg}^{-1}$ dry bw), whereas beetles collected near Miasteczko Śląskie smelter accumulated the highest concentrations of $\mathrm{Cd}$ (mean $3.7 \mathrm{mg} \mathrm{kg}^{-1}$ dry bw). Detailed data on the metal concentrations in the soils and beetles are given in Table 1.

The BCI increased with increasing PI $(p=0.009$, $\left.r^{2}=51.5 \%\right)$ and significant differences between the gradients were found in both regression intercepts $(p=0.0002)$ and slopes $(p=0.017)$. The beetles at MSL gradient had generally higher BCI and its increase was steeper (Fig. 1). The model explained $93.6 \%$ of total variance $\left(\mathrm{r}_{a d j}^{2}=91.2 \%\right)$ and was highly significant $(p<0.0001)$.

A significant difference was found in $\mathrm{R}$ between the two sampling years at the unpolluted site: the beetles collected in 2010 had higher respiration rate than those collected in $2008(p=0.01)$. The cellular respiration rates exhibited large variation (Table 1) and no difference between the years was found.

$\mathrm{R}$ increased with increasing $\mathrm{BCI}_{i}(p=0.014$, Fig. 2). The model included also body mass $(p<0.0001)$, year/ gradient $(p=0.0025)$ and interactions: $\mathrm{BCI}_{i} \times$ wet body mass $(p=0.018), \mathrm{BCI}_{i} \times$ collection day $(p=0.006)$ and gradient (or sampling year) $\times$ wet body mass $(p=0.014)$ (Table 2), and explained $38.7 \%$ of the total variability $\left(\mathrm{r}_{a d j}^{2}=37.6 \%\right)$.

Neither PI nor gradient/sampling year was found to affect mean ETS, but the mean R was lower at OLK (2008 sampling) than at MSL gradient (2010 sampling) $\left(p<0.0001, \mathrm{r}_{a d j}^{2}=88.2 \%\right)$. No significant relationship between mean $\mathrm{R}$ and mean ETS was found.

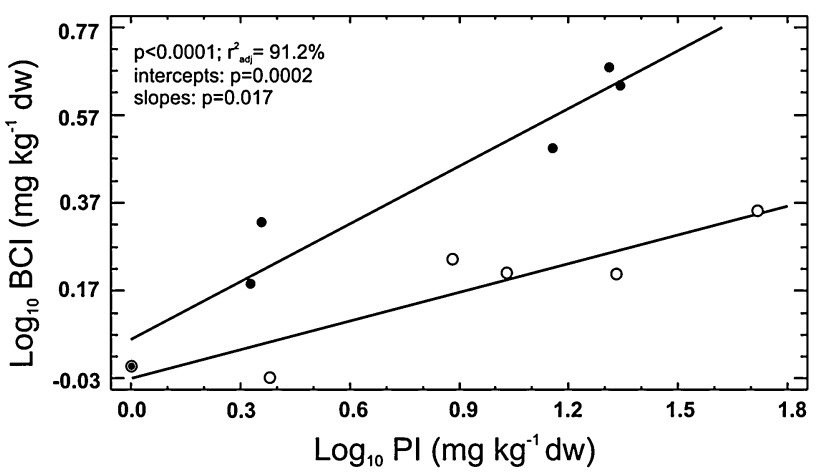

Fig. 1 Effect of metal concentration in soil (expressed as pollution index, PI) on the internal body concentration of metals (expressed as body concentration index, BCI) in $P$. oblongopunctatus collected along two pollution gradients $\left(p<0.0001, \mathrm{r}_{a d j}^{2}=91.2 \%\right.$, difference in intercepts: $p=0.0002$, difference in slopes: $p=0.017$ ); open circles, OLK; full circles, MSL

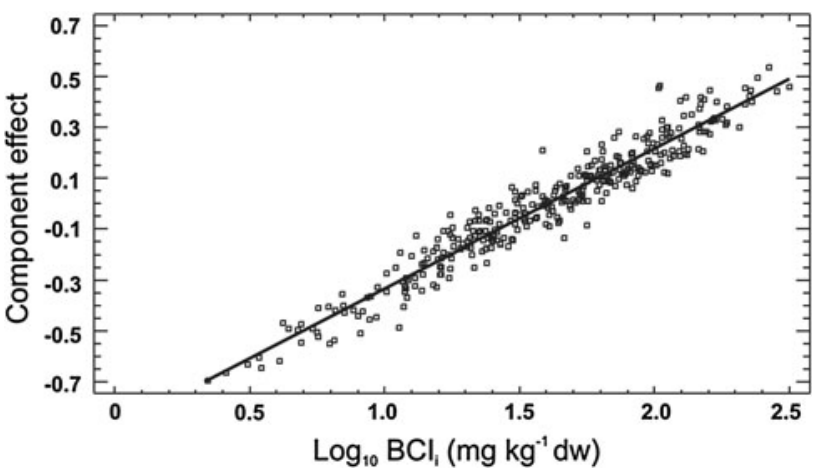

Fig. 2 Results of the multiple regression analysis: effect of body concentration of metals expressed as body concentration index, $\mathrm{BCI}_{i}$ on the whole-body respiration rate of $P$. oblongopunctatus collected along two pollution gradients. The line shows the relative change in the predicted values of respiration rates that occurs when changing body concentration of metals over their observed ranges. Each point is then plotted by adding its residuals to a line. The respiration rate correlates with $\mathrm{BCI}_{i}$ at $p=0.014$. The model included also body mass $(p<0.0001)$, year (or gradient) $(p=0.0025)$ and interactions: $\mathrm{BCI}_{i} \times$ wet body mass $(p=0.018), \quad \mathrm{BCI}_{i} \times$ collection day $(p=0.006)$ and year (or gradient) $\times$ wet body mass $(p=0.014)$, and explained $38.7 \%$ of the total variability $\left(\mathrm{r}_{a d j}^{2}=37.6 \%\right)$

Table 2 The results of fitting a multiple linear regression model to describe the relationship between the whole-body respiration rate and independent variables and their interactions

\begin{tabular}{lcccc}
\hline Model term & $\begin{array}{l}\text { Coefficient } \\
\text { estimates }\end{array}$ & SE & $\begin{array}{l}\text { Statistic } \\
T\end{array}$ & $p$ value \\
\hline Constant & 0.796 & 0.3568 & 2.229 & 0.026 \\
$\mathrm{BCI}_{i}$ & 0.550 & 0.2228 & 2.467 & 0.014 \\
Body mass & -1.400 & 0.2665 & -5.252 & $<0.0001$ \\
Year/gradient & 0.350 & 0.1146 & 3.052 & 0.0025 \\
$\mathrm{BCI}_{i} \times$ wet body mass & 0.511 & 0.1622 & 3.149 & 0.018 \\
$\mathrm{BCI}_{i} \times$ collection day & 0.001 & 0.0004 & 2.791 & 0.006 \\
$\begin{array}{l}\text { Year/gradient } \times \text { wet } \\
\text { body mass }\end{array}$ & 0.278 & 0.086 & 3.217 & 0.014 \\
\hline
\end{tabular}

\section{Discussion}

Chronic exposure to environmental pollutants doesn't have to be lethal and some species of carabids are able to maintain viable populations in areas highly contaminated with metals (Skalski et al. 2011). However, they may still incur physiological costs associated with metal exposure. There are a priori grounds for expecting physiological costs associated with processes deployed to cope with exposure to contaminants (Forbes and Calow 1996). It is generally accepted that coping with stress (defense) or repairing damages (alterations) implies energy costs connected with re-allocation of resources favoring tolerance to stress (Calow 1991). The energy expended to defense is no longer available for maintenance, growth and reproduction, suggesting potential 
effects on the health status of organisms and the fate of populations. Indeed, populations of $P$. oblongopunctatus inhabiting metal-polluted areas on the OLK gradient have been previously demonstrated to be sensitive to the additional stressors (Stone et al. 2001) and have reduced fertility (Łagisz and Laskowski 2002).

The depletion of an animal's energy reserves or increase in its metabolic rates have been associated with the toxicity of metals, such as cadmium and zinc (Moolman et al. 2007). In our previous study we did not observe the depletion of energy reserves with increasing metal contamination in the beetles collected along the same gradients of pollution (Bednarska et al. 2012). This study, however, has demonstrated significant energetic costs associated with living in metal contaminated areas. Given that respiration rate is an indirect measure of an organism's maintenance costs, the observed increase of $\mathrm{R}$ with increasing $\mathrm{BCI}_{i}$ suggests that $P$. oblongopunctatus incurred energetic expenditures, presumably as a result of energy required to facilitate metal elimination or repair toxicantinduced cellular damage (Calow 1991). The metabolic (and fitness) costs associated with metal resistance were also observed in other species (harbour ragworms Nereis diversicolor, Pook et al. 2009; bullfrog tadpoles Rana catesbeiana, Rowe et al. 1998). The increase of $\mathrm{R}$ with increasing $\mathrm{BCI}_{i}$, but lack of such relationships between metal concentrations in soil or body metal concentrations and the whole-organism or cellular respiration rate when using mean values per site, suggest the importance of incorporating individual variability in analyses of respiration rate data.

Although the liner relationship between R and ETS was shown for 15 marine zooplankton species (King and Packard 1975), we did not find such a relationship in P. oblongopunctatus. In general, we found much higher ETS values compared to $\mathrm{R}$. This can be explained by the fact that the applied method measures the maximum ETS activity under saturated substrate concentrations. Thus, ETS is a biochemical measure of the potential maximal metabolic activity and it shows the value of oxygen consumption that would occur if all enzymes worked at their maximum capacity. The energy consumed at the cellular level is measured as instantaneous enzyme activity which is a snapshot view of energy consumption but not integration over time of what the cell has actually consumed (Olsen et al. 2007). On the other hand, R can represent long-term effects because organisms have to handle toxic chemicals as long as their body concentrations are elevated and even after their detoxification and/or excretion, damage repair may still require significant amounts of energy (Forbes and Calow 1996).

Respiratory metabolism is one of the main components of an energy budget and, at the same time, one of the most sensitive to both internal and external factors (e.g., sex, body mass, physiological state) (Chaabane et al. 1999). Therefore, to avoid possible large variation caused by sex-specific metabolism and physiological state of beetles, only males were used in this study. The body mass of beetles and collection date were taken into account in statistical analysis of R. However, it was not possible to collect and measure animals from both gradients in the same year, so we could not avoid the possible differences between the years, e.g., in weather conditions. Indeed, the higher whole-body respiration rate in control beetles collected in 2010 could be, at least partly, the consequence of a severe winter preceding the 2010 sampling (meteorological data from the Research Station of the Institute of Geography and Spatial Management, Jagiellonian University, in Gaik-Brzezowa, Wieliczka Foothills). Our earlier laboratory study on the same species showed that the temperature at which the beetles were cultured affected their respiration, even if the respiration rate was always measured at the same constant temperature for all beetles $\left(20{ }^{\circ} \mathrm{C}\right)$ : animals originating from lower temperatures had higher respiration rates (Bednarska and Laskowski 2008). It is not possible to discriminate between the effect of year (e.g., difference in the weather) and the effect of gradient as such in the present study. However, irrespectively of possible differences between the years or gradients, the strong relationship between $\mathrm{R}$ and $\mathrm{BCI}_{i}$ found in this study allows for more general conclusions about the cost, in bioenergetic terms, of tolerance to metals. In addition, our findings are consistent with physiological responses documented by Łagisz and Laskowski (2002) for the same species. The authors found a positive relationship between respiration rates of males of $P$. oblongopunctatus from an F1 generation fed uncontaminated food in the laboratory and zinc concentration at the sites from which their parents were collected. Although the study by Łagisz and Laskowski (2002) attempted to separate the effect of possible adaptation to metal contaminated environment from the direct toxic effect of metals, their further study did not reveal the genetic adaptation to metal pollution (Lagisz and Laskowski 2008).

To conclude, our results suggest that $P$. oblongopunctatus are able to survive in metal-polluted environments, but coping with high body metal concentrations has significant impact on their energy metabolism.

Acknowledgments The authors thank Renata Śliwińska for help in the field work. Ryszard Laskowski provided helpful comments on this manuscript. We also would like to thank the Olkusz Forest Service and Świerklaniec Forest Service for kind cooperation. The study was supported by the Polish Ministry of Science and Higher Education (Project No. N N304 025134) and Jagiellonian University (DS 759). A. J. Bednarska was sponsored by the Foundation for Polish Science, START Programme.

Open Access This article is distributed under the terms of the Creative Commons Attribution License which permits any use, distribution, and reproduction in any medium, provided the original author(s) and the source are credited. 


\section{References}

Bednarska AJ, Laskowski R (2008) Effects of nickel and temperature on the ground beetle, Pterostichus oblongopunctatus (Coleoptera: Carabidae). Ecotoxicology 17:189-198

Bednarska AJ, Stachowicz I, Kuriańska L (2012) Energy reserves and accumulation of metals in the ground beetle Pterostichus oblongopunctatus from two metal-polluted gradients. Environ Sci and Pollut R. doi:10.1007/s11356-012-0993-y

Calow P (1989) Physiological ecotoxicology: theory, practice and application. In Lokke $\mathrm{H}$, Tyle $\mathrm{H}$, Bro-Rasmussen $\mathrm{F}$ (ed) Proceedings of the first European conference on ecotoxicology, conference organizing committee, Lyngby, pp 23-25

Calow P (1991) Physiological costs of combating chemical toxicants: ecological implications. Comp Biochem Physiol C 100:3-6

Chaabane K, Josens G, Loreau M (1999) Respiration of Abax ater (Coleoptera, Carabidae): a complex parameter of the energy budget. Pedobiologia 43:305-318

De Coen WM, Janssen CR (1997) The use of biomarkers in Daphnia magna toxicity testing: IV. Cellular energy allocation: a new methodology to assess the energy budget of toxicant-stressed Daphnia populations. J Aquat Ecosyst Stress Recover 6:43-55

De Coen WM, Janssen CR (2003) The missing biomarker link: relationships between effects on the cellular energy allocation biomarker of toxicant-stressed Daphnia magna and corresponding population characteristic. Environ Toxicol Chem 22:1632-1641

Forbes VE, Calow P (1996) Cost of living with contaminants: implications for assessing low-level exposures. BELLE (Biological Effects of Low Level Exposures) Newsletter 4(3):1-8

Handy RD, Depledge MH (1999) Physiological responses: their measurements and use as environmental biomarkers in ecotoxicology. Ecotoxicology 8:329-349

Hopkin SP (1989) Ecophysiology of metals in invertebrates. Elsevier, Applied Science, London

Jones DT, Hopkin SP (1998) Reduced survival and body size in terrestrial isopod Porcellio scaber from a metal-polluted environment. Environ Pollut 99:215-223

Kenner RA, Ahmed SI (1975) Measurements of electron transport activities in marine phytoplankton. Mar Biol 33:119-127

King FD, Packard TT (1975) Respiration and the activity of the respiratory electron transport system in marine zooplankton. Limnol Oceanogr 20:849-854

Kramarz P, Kafel A (2003) The respiration rate of the beet armyworm pupae (Spodoptera exigua) after multi-generation intoxication with cadmium and zinc. Environ Pollut 126:1-3

Lagisz M, Laskowski R (2008) Evidence for between-generation effects in carabids exposed to heavy metals pollution. Ecotoxicology 17:59-66

Łagisz M, Laskowski R (2002) Respiratory metabolism in Pterostichus oblongopunctatus originating from metal contaminated and reference areas. Fresen Environ Bull 11:74-77

Lagisz M, Kramarz P, Niklinska M (2005) Metal kinetics and respiration rates in $\mathrm{F} 1$ generation of carabid beetles (Pterostichus oblongopunctatus $\mathrm{F}$.) originating from metal-contaminated and reference areas. Arch Environ Contam Toxicol 48:484-489
Łagisz M, Laskowski R, Kramarz P, Tobor M (2002) Population parameters of the beetle Pterostichus oblongopunctatus F. from metal contaminated and reference areas. Bull Environ Contam Toxicol 69:243-249

Laskowski R, Maryański M, Pyza E, Wojtusiak J (1996) Sublethal toxicity tests for long-lived invertebrates: searching for a solution. In: Van Straalen NM, Krivolutsky DA (eds) Bioindicator systems for soil pollution NATO ASI series, 2: environment. Kluwer, London, pp 45-55

Lukasik P, Laskowski R (2007) Increased respiration rate as a result of adaptation to copper in confused flour beetle, Tribolium confusum Jacquelin du Val. Bull Environ Contam Toxicol 79:311-314

Migula P (1989) Combined and separate effects of cadmium, lead and zinc on respiratory metabolism during the last larval stage of the house cricket, Acheta domesticus. Biologia (Bratisl) 44:513-521

Moolman L, Van Vuren JHJ, Wepener V (2007) Comparative studies on the uptake and effects of cadmium and zinc on the cellular energy allocation of two freshwater gastropods. Ecotoxicol Environ Saf 68:443-450

Olsen GH, Sva E, Jarroll J, Camus L, De Coen W, Smolders R, Řveraas H, Hylland K (2007) Alterations in the energy budget of Arctic benthic species exposed to oil-related compounds. Aquat Toxicol 83:85-92

Pook C, Lewis C, Galloway T (2009) The metabolic and fitness costs associated with metal resistance in Nereis diversicolor. Mar Pollut Bull 58:1063-1071

Posthuma L, Van Straalen NM (1993) Heavy-metal adaptation in terrestrial invertebrates: a review of occurrence, genetics, physiology and ecological consequences. Comp Biochem Physiol C 106:11-38

Rowe CL, Kinney OM, Nagle RD, Congdon JD (1998) Elevated maintenance costs in an anuran (Rana catesbeiana) exposed to a mixture of trace elements during the embryonic and early larval periods. Physiol Zool 71:27-35

Sibly RM, Calow P (1989) A life-cycle theory of responses to stress. Biol J Linn Soc 37:101-116

Skalski T, Gargasz K, Laskowski R (2011) Does mixed diffused pollution decrease ground beetle diversity? Baltic J Coleopterol 11:1-15

Stefanowicz AM, Niklińska M, Laskowski R (2008) Metals affect soil bacterial and fungal functional diversity differently. Environ Toxicol Chem 27:591-598

Stone D, Jepson P, Kramarz P, Laskowski R (2001) Time to death response in carabid beetles exposed to multiple stressors along a gradient of heavy metal pollution. Environ Pollut 113:239-244

Tarasek A (2011) Heavy metal effect on activity and functional diversity of soil microbial communities in Miasteczko Śląskie area. Dissertation, Jagiellonian University

Walker CH, Hopkin SP, Sibly RM, Peakall DB (2006) Principles of ecotoxicology, 3rd edn. Taylor and Francis, Boca Raton

Wilczek G, Babczyńska A, Augustyniak M, Migula P (2004) Relations between metals ( $\mathrm{Zn}, \mathrm{Pb}, \mathrm{Cd}$ and $\mathrm{Cu}$ ) and glutathionedependent detoxifying enzymes in spiders from a heavy metal pollution gradient. Environ Pollut 132:453-461 